\title{
Radikaalia uudelleen ajattelua
}

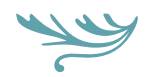

TYÖVOIMATUTKIMUKSEN (2013) mukaan työllisistä alle 65 -vuotiaista $40 \%$ työskentelee vähintään asiantuntijatason osaamista vaativissa työtehtävissä. Tarkastelen tässä työuralla tapahtuvan osaamisen kehittämisen haasteita nimenomaan asiantuntijatyötä tekevän, korkeasti koulutetun näkökulmasta.

Pelkän aikuiskoulutuksen kehittäminen tulevaisuudessa ei itsessään riitä, vaan kehittämiskohteita ovat esimerkiksi myös työn johtaminen, yhtä työpaikkaa laajemmat verkostot, koulutuksen rahoitusjärjestelmät sekä verotus.

Työmarkkinoilla tapahtunut muutos on jo haastanut työuran alussa opiskeltavien pitkien kertatutkintojen ajatuksen. Työssä olon ja työstä oppimisen sekä muodollisen kouluttautumisen ja työn kehittämisen kietoutuminen yhteen on täysin ilmeistä.

Koulutus- ja työmarkkinoiden sopimusjärjestelmä, toimeentulon muodot sekä koulutuksen rahoitusjärjestelmä ovat tipahtaneet kuitenkin vaatimusten kyydistä. Yhä useamman korkeasti koulutetun työuralle osuu myös työttömyysjakso, jonka tulisi olla mahdollisimman lyhyt.

\section{MUODOLLISTA KOULUTUSTA EI ARVOSTETA}

Asiantuntijoiden koulutuksessa tulisi ymmärtää nykyistä paremmin muodollisen koulutuksen merkitys osana systemaattista osaamisen kehittymistä. Tämä edellyttää, että kaikkien alojen asiantuntijoille on tarjolla erilaisiin tarpeisiin kohtuuhintaista koulutusta.

Akavan TNS-Gallupilla 2013 teettämän kyselyn mukaan Akavalaiset saivat keskimäärin 4,8 työnantajan kustantamaa koulutuspäivää, ja kolmannes akavalaisista ei päässyt osallistumaan koulutukseen edes yhtä päivää. $80 \%$ vastaajista kuitenkin kokee tarvitsevansa seuraavan kahden vuoden aikana koulutusta, lähinnä lyhytkestoista, omaa osaamista täydentävää.
Noin viiden vuoden välein tilastokeskuksen tekemän laajan aikuiskoulutustutkimuksen tulokset osoittavat myös, että korkea-asteen suorittaneiden osallistuminen henkilöstökoulutukseen on koko ajan laskenut vuoden 2000 jälkeen. Huolta ei ainakaan lievennä, että yrityksistä yli puolet käytti viime vuonna kouluttamiseen tapahtumia eli messuja ja yritysvierailuja. Ei olekaan ihme, että "aikuiskoulutus" leimataan aina välillä aikuisten hupipäiviksi.

Huolestuttavia ovat myös viestit palkansaajien omista näkemyksistä koulutuksen tarpeesta. Jo edellä mainittu TNS-Gallup kertoo, että reilu kymmenys miehistä katsoi, ettei tarvinnut mitään koulutusta. Yli 50-vuotiasta jopa $15 \%$ katsoi, ettei tarvitse koulutusta. Työtehtävät muuttuvat kuitenkin jatkuvasti vaativammiksi, ja korkeasti koulutettu kehittää usein työkseen myös koko yritystä tai organisaatiota. Vaativan työn ohessa asiantuntijan on kehitettävä jatkuvasti tavoitteellisesti myös itseään, varmistaakseen työpaikan tai saadakseen uuden mikäli senhetkinen työpaikka menisi alta.

\section{KEHITTYYKÖ YKSILÖ VAI YHTEISÖ?}

Asiantuntijan kouluttaminen on usein vielä liian yksilölähtöistä. Tämä heijastelee koulutusjärjestelmämme ja sen arvioinnin lähtökohtia. Tutkimusten mukaan paras korkeakoulutettujen jatko- ja täydennyskoulutus edellyttää sellaisten koulutusratkaisujen toteuttamista, joissa muodollinen koulutus pohjautuu asiantuntijoiden työkäytäntöjen reflektiiviseen tarkasteluun teoreettisten välineiden avulla (Onnismaa 2013,29). Tämä asettaa sekä muodollisen koulutuksen että työpaikkojen työkäytännöt aivan uudenlaisten vaatimusten eteen.

Harva selviää työtehtävistään hyvin enää yksin puurtamalla ja harvaa ongelmaa ratkaistaan yksittäisen ihmisen tai edes yhden asiantuntijuusalan 
osaamisella. Asiantuntijatyö on taas - tai sen tulisi olla - luonteeltaan kollektiivista, verkostoitunutta, ja myös toiminnan laadun kriteerit asetetaan näissä vertaisryhmissä (Onnismaa 2013, 27). Aikuis- ja täydennyskoulutuksen sekä osaamisen johtamisen työpaikoilla tulisi heijastella näitä vaatimuksia.

Asiantuntija kyllä oppii jatkuvasti työssään, mutta oppiminen ei ole useinkaan tavoitteellista eikä omaa osaamista osata sanoittaa. Omat työtavat ja ajattelun rakenteet voivat olla kankeutuneet, mutta kehittämisen tarvetta ei itse edes tiedosteta. Muodollisen koulutuksen tärkeimpiä tavoitteita olisikin onnistua herättämään asiantuntijat sekä yksilöinä että verkostoina näkemään syvempien toimintatapojen muutostarpeet. Tähän tarvittaisiin kuitenkin pidempikestoista, prosessinomaista koulutusta. Jotta muutos tapahtuu myös organisaation tasolla, koko johtamiskulttuuria pitäisi miettiä osaamisen johtamisen ja asiantuntijoiden motivaation kautta eikä organisaatiokaavioiden kautta.

Juuri lainsäädännöllisen perustansa saaneet erikoistumiskoulutukset ovatkin yksi mahdollisuus luoda uudenlaisia työelämälähtöisiä, mutta uusimpaan tietoon ja teoriaperustaan pohjautuvia asiantuntijakoulutuksia korkeasti koulutetuille. Niiden kunnianhimoinen toteuttaminen edellyttää myös korkeakouluilta paljon, sillä niiden on nähtävä asiantuntijoiden koulutus osana strategista tehtäväänsä ja yhteiskunnallisen tehtävän muotona. Erikoistumiskoulutusten lisäksi myös avoimen korkeakoulutuksen tarjontaa sekä markkinaperusteista koulutusta on kehitettävä palvelemaan joustavasti asiantuntijoiden osaamisen kehittymisen tarpeita. Työantajien pitää myös tunnistaa uudet koulutusmuodot ja tarjota mahdollisuuksia "uusille urille" pyrkiville asiantuntijoille.

Monelle asiantuntijalle tärkeä tapa kehittyä ovat uudet työtehtävät oman organisaation sisällä. Työnantajalla on paljon mahdollisuuksia vaikuttaa työntekijän kehittymiseen, mutta myös asiantuntijan on itse oltava aloitteellinen ja tavoitteellinen. Työtehtävien muutosta tulisi tukea myös muodollisella koulutuksella, jotta asiantuntijuus kehittyy täyteen mittaansa myös uudella osaamisalueella. Usein lyhytkin koulutus vaatii järjestelyjä ja priorisointeja, jolloin esimiehen tuki on äärimmäisen tärkeää. Kehittynyt osaaminen on myös tärkeää oppia sanoittamaan riittävän yksityiskohtaisesti, jotta työpaikkaa vaihdettaessa käytettävissä ovat muutkin kuin ansioluetteloiden vakiotekstit.

Ura- ja muun ohjauksen merkitys osana omaa kehittymistä ja hyvää täydennyskoulutusta on ymmärretty asiantuntijoiden piirissä jo pitkään. Tästä huolimatta työelämässä olevien aikuisten ohjauspalvelut ovat vielä täysin kehittymättömiä eikä tarve ole muuttunut kulutuskysynnäksi. Uraohjaus on pahasti myöhässä, jos sitä haetaan vasta työttömyyden kohdatessa.

\section{RAHOITUSTA TOIMEENTULOON JA OPISKELUN KUSTANNUKSIIN}

Aikuisten koulutuksessa on toisinaan tarvetta pidemmille omaehtoisille koulutusjaksoille. Tällöin toimeentulon turvaavat etuudet ovat olennainen osa aikuisten oppimisen edellytyksiä. Korkeasti koulutetun intensiivinen opiskelu pitkään työn ja muun elämä ohessa on usein liian raskasta. Esimerkiksi alan vaihdon kohdalla pitkä opiskelu on toisinaan kuitenkin välttämätöntä. Turbulentti työelämä pakottaa yhä useammin vaihtamaan ammattia kokonaan ja tämä voi edellyttää myös pidempää tutkintoon johtavaa tai muuta koulutusta.

Vuonna 2010 tehtiin kaksi merkittävää korkeasti koulutettujenkin opiskelua edistävää uudistusta, kun aikuiskoulutustuen taso nousi ansiosidonnaisen työttömyysturvan tasoiseksi. Samoin omaehtoinen opiskelu työttömyysturvalla tuli mahdolliseksi, mikäli opiskelun vahvistetaan työllistymissuunnitelmassa edistävän yksilön mahdollisuuksia työllistyä. Nämä toimeentuloa turvaavien etuuksien uudistukset ovat olleet olennaisen tärkeitä ja tarjoavat pisimmillään kahden vuoden (omaehtoinen opiskelu työttömyysetuudella) tai 19 kuukauden (aikuiskoulutustuki) opiskelun.

Toimeentulon rahoituksen lisäksi myös koulutuksen kustannuksiin on etsittävä uusia rahoituskeinoja. Suomessa maksuton tutkintoon johtava koulutus ja muun kohtuuhintaisen koulutustarjonnan vähyys sekä toimeentulon turvaavien etuuksien paraneminen ovat aiheuttaneet sen, että tutkintoon johtavaa koulutusta käytetään täydennyskoulutuksena. Tämä on monella tapaa epätarkoituksenmukaista. Tilanne on johtanut siihen, että ainoastaan $60 \%$ 
uusista opiskelijoista on todella aitoja uusia opiskelijoita, ja toiselta asteelta siirtyminen korkea-asteelle viivästyy useita vuosia.

Myös kuluneella hallituskaudella on etsitty rahoituksesta keinoja vahvistaa erilaisten yksilöiden tarpeista lähtevää koulutustarjontaa. Ministeri Gustafsson antoi vaalikauden alussa allekirjoittaneen ja kasvatustieteen professori Erno Lehtisen selvitettäväksi, voitaisiinko kansalaisten henkilökohtaisilla koulutustileillä tukea kouluttautumista ja luoda kulutuskysynnän avulla paremmin tarkoituksiin vastaavaa koulutusta (Lehtinen, Mielityinen 2012).

Erityisesti julkisen talouden heikko tilanne pakottaa etsimään uusia rahoituksellisia instrumentteja, joilla voidaan kannustaa myös yksilöitä sekä työnantajia käyttämään enemmän rahaa osaamisen kehittämiseen. Lisäraha ohjaisi myös koulutuksen tarjontaa vastaamaan paremmin moninaisen ja myös pienten ryhmien kysynnän tarpeita.

\section{UUDELLEENAJATTELUA JA ASENTEIDEN MUUTOSTA KAIVATAAN}

Akava katsookin, että "yhteiskuntasopimuksemme" osaamisen kehittämisestä on päivitettävä kilpailukykymme vaatimusten tasolle. Osaamisen kehittämisen rahoituksesta on sovittava sitovasti työ- ja virkaehtosopimuksissa. Yksilön mahdollisuuksia osallistua maksulliseen täydennyskoulutukseen on vahvistettava sopimalla kolmikantaisesta rahoitusmallista. Tarvitsemme uudenlaisia rahoituksellisia muotoja, ja verotuksella on kannustettava sekä työnantajia kouluttamaan että yksilöitä kouluttautumaan.

Kestävät asiantuntijaurat voivat toteutua tulevaisuudessa ainoastaan, mikäli työssä tapahtuva oppiminen on systemaattista ja tavoitteellista. Oppimista voidaan taas tukea muodollisella uusimpaan tietoon pohjautuvalla koulutuksella, joka huomioi sekä yksilön että työn kehittämisen tavoitteet.

Radikaalin uudelleenajattelun tarpeita on siis niin työnantajien kuin työntekijöidenkin asenteissa, koulutuksen tarjonnassa, koulutuksen toteutuksessa ja pedagogiikassa, toimeentulon turvaavien etuuksien kohdentumisessa, verotuskäytännöissä sekä koulutuksen rahoituspohjassa.

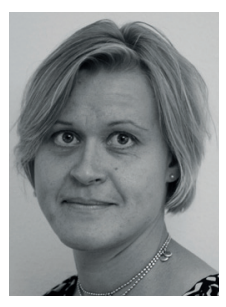

Ida Mielityinen

VTM, koulutuspolitiikan asiantuntija Akava

\section{LÄHTEET}

Lehtinen, E. \& Mielityinen, I. (2012). Selvitys henkilökohtaisista koulutustileistä. Ehdotukset ja vaikuttavuuden arviointi. Opetus- ja kulttuurinministeriön työryhmämuistioita ja selvityksiä 2012:27.

Onnismaa, J. (2013). Ohjausdialogin laatu korkeakoulujen työelämälähtöisessä täydennyskoulutuksessa. Teoksessa Rouhesalo \& Trapp (toim.) Tulevaisuuden asiantuntijuutta rakentamassa. Turun yliopiston koulutus- ja kehittämiskeskus Brahean julkaisuja B:1. 